\title{
Obtention of Taro Flour (Colocasia esculenta L.) and Its Potential in Bread Making
}

\author{
Armindo Paixão ${ }^{1, *}$, João Cardoso ${ }^{2}$, André Loução ${ }^{2}$, Deolinda Embaló ${ }^{1}$, Clenice Costa ${ }^{3}$, Ataulfo M. A. F. \\ Pereira $^{4}$, Luzidia Filemone ${ }^{5}$, Cristóvão Simões ${ }^{1}$, Joaquim Morais ${ }^{1}$ \\ ${ }^{1}$ Faculty of Veterinary, José Eduardo dos Santos University, Huambo, Angola. \\ ${ }^{2}$ Faculty of Agricultural Sciences, José Eduardo dos Santos University, Huambo, Angola. \\ ${ }^{3}$ Central Laboratory for Food and Agriculture, Luanda, Angola. \\ ${ }^{4}$ Cuito Cuanavale University, Cuando Cubango, Angola. \\ ${ }^{5}$ Faculty of Human Sciences, Social and Culture, Agostinho Neto University, Angola.
}

How to cite this paper: Armindo Paixão,
João Cardoso, André Loução, Deolinda
Embaló, Clenice Costa, Ataulfo M. A. F.
Pereira, Luzidia Filemone, Cristóvão
Simões, Joaquim Morais. (2021) Obtention
of Taro Flour (Colocasia esculenta L.) and
Its Potential in Bread Making. Internation-
al Journal of Food Science and Agricul-
ture, 5(3), 393-398.
DOI: 10.26855/ijfsa.2021.09.009

Received: June 15, 2021

Accepted: July 10, 2021

Published: July 28, 2021

*Corresponding author: Armindo Paixão, Faculty of Veterinary, José Eduardo dos Santos University, Huambo, Angola.

Email: armindo7000@hotmail.com

\begin{abstract}
In order to obtain taro flour and make breads, tubers were purchased in the vicinity of the Santo António neighborhood in the Huambo, which were transported in polyethylene bags and subsequently cleaned in running water, peeled by hand with a knife, sanitized with acidified water with lemon and cut into pieces, then proceeded to dry directly in the sun and after seven days they were crushed in a traditional mortar, subsequently the sifting was carried out, then it was packed and kept in a refrigerator for late use, from this process the white colored flour was obtained that served for the preparation of breads, this products with different levels of inclusion were constituted in formulations of $30 \%$ and $50 \%$, all presented attributes considered acceptable when reaching acceptability scales greater than 4 points with the exception of the softness attribute in the formulation of $100 \%$ taro which reached only 3.93 points.
\end{abstract}

\section{Keywords}

Taro Flour, Bread, Attributes, Sensory Analysis

\section{Introduction}

Taro flour is a stable form of developing by-products for healthy food market and for special uses [1-2], due to its high fibre content [3] and for conferring functional properties to products made from this tuber flour [4]. The carbohydrate content of this flour in the form of starch is between $70 \%-80 \%$, with features indicating very fine grains that give it a digestibility of $98.8 \%$ [5]. Its nutritional composition makes taro a very attractive raw material in the manufacturing of high nutritional value foods [6]. In this regard, Arici et al. [7], report the existence of proteins (11-16\%), crude fibre (5-9\%) and potassium (2,271-4,276 mg/100 g), in addition to other minerals such as iron, calcium, sodium, magnesium, phosphorus, zinc and copper. Several bioactive compounds such as sapogenin, alkaloids, tannins, glucosides, phenols, flavonoids and saponins are reported to exist in taro, which give these tuber excellent medicinal and nutritional properties that can be much further explored [8].

Recently, it has become common to transform taro into flour for the preparation of different types of food and bakery products such as bread and cakes [9]. Bread is one of the world's most popular foods, as it is a rich source of calories in human nutrition, and generally made from wheat flour [10]. Wheat stands out as the most important cereal used in bread making because of a protein it contains (gluten) with unique characteristics, which gives it viscoelasticity and smoothness [11]. As it is known, wheat is widely consumed in many African countries, coming third after corn and cassava with respect to calorie intake and supply [12]. Many research studies worldwide point to the increasing concern to replace wheat flour in order to reduce import costs, especially in developing countries, where there is a major negative 
implication in the economy [13], not to mention the growing demand and raising prices in the international market. Taro, because of its energy value due to its high content of carbohydrates and the absence of gluten, constitutes a new alternative for the development of new bakery products [14]. In Brazil, for example, taro has been used in food industries because of its nutritional, medicinal and pharmacological properties [15]. In terms of production, countries such as Nigeria, China and Cameroon stand out [16], but the region of Africa is, by far, the largest producer of this tuber, accounting for $86 \%$ of the global production [17].

The objective of this work was to obtain taro flour and produce bread with 100\% of this flour and a partial replacement of wheat flour in $50 \%$ and $30 \%$.

\section{Material and Methods}

The work was carried out between May and October 2020 at the Faculty of Veterinary Medicine, more precisely at the Food Technology Research Centre (CEPTA), where the flours were processed. The taro flour was produced following the methodology described by Dias et al. [15]. For this purpose, the taro was purchased near Santo António, from where it was transported in polyethylene bags and later washed in running water, peeled with sharp stainless steel knives and cut into pieces approximately $2 \mathrm{~mm}$ thick to facilitate drying. Then the taro was put to dry directly in the sun as described by Cunha et al. [18] with respect to the process of drying tubers and hard plant materials. After a drying period of seven days, the tubers were ground in a traditional mortar and passed through a $200 \mu \mathrm{m}$ sieve, weighed and packed in kraft paper bags, and kept refrigerated for later use. The dry matter and moisture were determined by gravimetric method, the ash by incineration in a muffle furnace at $550^{\circ} \mathrm{C}$. In order to determine the consumption habit and taste for the tuber, a survey was conducted among 130 potential taro consumers, using the semi-structured questionnaire proposed by Bernard [19]. In the implementation phase, the product formulation and baking were carried out at the Shoprite supermarket, followed by attribute analysis and a small-scale market evaluation through a sensory test applied to 15 untrained tasters made up of supermarket customers. Four formulations were prepared with different proportions of taro flour: of $100 \%, 50 \%, 30 \%$ and $100 \%$ of wheat flour as a control formulation.

To make the bread, several ingredients were used (flour, chemical yeast, common salt, vegetable oil and water), which were mixed homogeneously in a $25 \mathrm{~kg}$ mixer. Then, the dough was placed in a cutting tin to be divided and shape the bread, which was taken to a medium preheated oven at a temperature of 180 degrees Celsius and baked for 15 minutes at this temperature. For the sensory evaluation of attributes like odour, colour, softness, flavour and global shape, an acceptance test with a vertical mixed category scale was administered, using a 5-point structured hedonic scale, where 5 = I liked it a lot, 4 = I liked it a little, 3 = I didn't like it or dislike it, 2 = I disliked it a little and 1 = I disliked it a lot [20]. On the same form, consumers were asked to respond to a question about their intention to buy the bread, using a 5-point scale in which 5 = would certainly buy, $4=$ would probably buy, $3=$ might buy/might not buy, 2 $=$ would probably not buy, and 1 = certainly would not buy. The acceptability index was calculated from the average of the responses considering the maximum score [5] equal to 100\% [21]. All tasters [15] were untrained and signed an informed consent form.

\section{Statistical analysis}

The statistical analysis was performed using Simple Variance Analysis (ANOVA) and Tukey-HSD test for the minimum significant difference between the mean values, using the statistical program STATISTICA, version 7.0. The buying intention was calculated as a percentage.

\section{Results and Discussion}

The exploratory survey carried out on the knowledge and use of taro demonstrates the regular consumption of the tuber and a liking for it of $100 \%$ and $97 \%$ respectively by some residents of the municipality of Huambo. It was also noted that $100 \%$ of the respondents had never before seen or eaten bread made from taro flour and in different proportions from a mixture with wheat flour, so $82 \%$ expressed their intent to purchase if it was available on the market and the price was no problem.

The peeling, drying, spraying and sifting process resulted in fine greyish-white flour that had $9 \%$ moisture, $2.24 \%$ ash and $90.95 \%$ of dry matter. As it can be observed, the humidity is within the acceptable limits, since the pharmacopoeias, according to Cunha et al. [18], establish a limit of $10 \%$ of humidity for dehydrated plant products, what demonstrates the possibility of being microbiologically safe, and thus there will be no reduction in stability and useful life [22]. The ash content obtained in this study (2.24) is similar to that found by Sharma et al. [23] and by Miomoto [24], which was 2.2 and 2.42\%, respectively, but lower than that observed by Sá et al. [25], estimated in 3.14\%, whereas the studies by Arici et al. [7] found values between 1.64\%-3.11\%. The moisture content obtained by Sá et al. [25] was 9.71\%, which is similar to the result achieved in this study (9\%).

As flours are part of the regular consumption of the Angolan population, it becomes essential to find viable, healthy 
and sustainable alternatives as a form of consumption and raw material for the production of other products such as bread. Studies indicate that taro flour can be used as a partial substitute for wheat flour in bakery products, thereby decreasing production costs and increasing the nutritional value of food products [26, 27]. The use of taro for flour production and manufacturing of various food products and for raw material for food industries is extremely important, with the additional advantage that this tuber can be found in large quantities in the provinces of Huambo, Cuanza Sul, Bié, Malanje, Uíge, Zaire, Cabinda, Cuando Cubango and Cuanza Norte, where farming is of subsistence and made by family farmers. These data can stimulate the commercial use of taro with a view to transforming it into flour for various purposes and increasing the consumption habit.

Studies by Mongi et al. [27] and Ndabikunze et al. [28] refer to the commercial use of taro as a viable alternative to reducing imports of wheat flour to developing countries. Angola has great potential as regards to the growing of this tuber due to its arable soils and water resources, in addition to the rusticity and productivity of taro, which can sustain large-scale flour production and, consequently, meet the market demands in relation to products derived from this flour and the tuber itself.

The growing of taro was suggested by the FAO (Food and Agriculture Organization) as an alternative to increase the food basis of developing countries, due to its rusticity characteristics and nutritional value, in order to also reinforce their food security [29]. Besides the compounds already mentioned, taro contains a high content of unsaturated fatty acids, such as linoleic acid (omega-6) and linolenic acid (omega-3), in addition to antioxidant compounds, anthocyanins and phytosterols that make it a functional food since they are bioactive compounds [30].

\section{Bread production from plain taro flour and with different mixtures}

After the entire formulation process, different types of bread were obtained, with $100 \%$ taro flour and others whose proportion of mixture with wheat flour was 50 and 30\%, as shown in Figure 1.

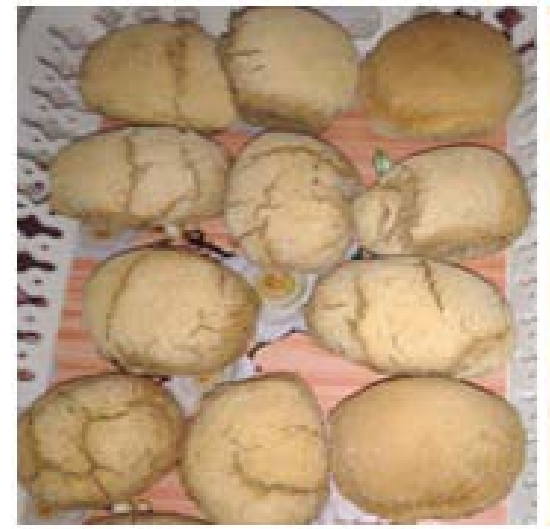

a

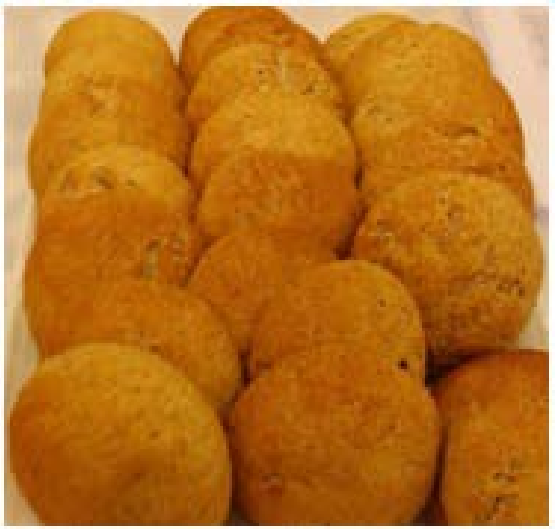

$\mathrm{b}$

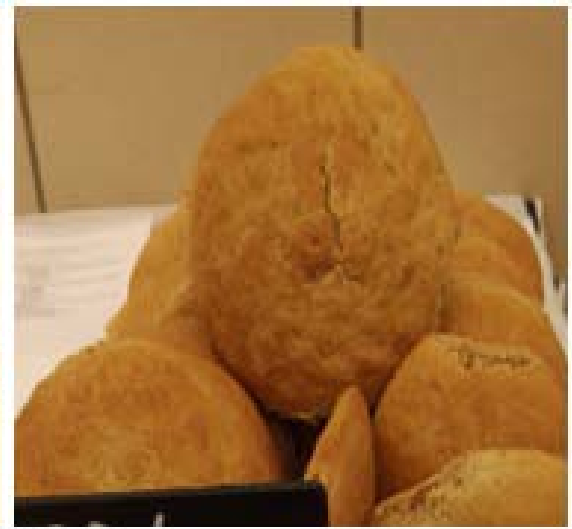

C

Figure1. Appearance of the bread. a) $100 \%$ t, b) $50 \%$ t, c) $30 \% \mathrm{t}$.

Table 1. Comparison between the averages $( \pm d s)$ of the attributes of different formulations

\begin{tabular}{cccccc}
\hline Formulations & Odour & Taste & Smoothness & Colour & Overall shape \\
\hline $100 \% \mathrm{tf}$ & $4.53 \pm 0.7^{\mathrm{a}}$ & $4.27 \pm 1.0 \mathrm{a}$ & $3.93 \pm 1.2 \mathrm{~b}$ & $4.67 \pm 0.6 \mathrm{a}$ & $4.13 \pm 1.5 \mathrm{a}$ \\
$50 \% \mathrm{tf}$ & $4.87 \pm 0.3^{\mathrm{a}}$ & $4.53 \pm 1.0 \mathrm{a}$ & $4.93 \pm 0.2^{\mathrm{a}}$ & $4.93 \pm 0.2 \mathrm{a}$ & $5 \pm 0.0 \mathrm{a}$ \\
$30 \% \mathrm{tf}$ & $4.80 \pm 0.4^{\mathrm{a}}$ & $4.73 \pm 0.4 \mathrm{a}$ & $4.87 \pm 0.3^{\mathrm{a}}$ & $4.67 \pm 1.0 \mathrm{a}$ & $4.53 \pm 1.0 \mathrm{a}$ \\
$100 \% \mathrm{wf}$ & $4.93 \pm 0.2^{\mathrm{a}}$ & $5 \pm 0.0 \mathrm{a}$ & $5 \pm 0.0 \mathrm{a}$ & $5 \pm 0.0 \mathrm{a}$ & $5 \pm 0.0 \mathrm{a}$ \\
\hline
\end{tabular}

Equal letters in the same column have no significant differences at $\mathrm{p}<0.05$ level. $\mathrm{t}$ (taro), w (wheat).

The sensorial analysis showed a good consumer acceptability of the formulated types of bread, and, as observed, the three types presented averages higher than 4 scores in all the attributes. Exception goes to the softness attribute in the formulation of $100 \%$ taro, in which the average obtained was 3.93, what means a positive acceptance of the products. As shown in Table 1, there was no significant difference in attributes (odour, overall shape, flavour, colour and softness) between the different formulations, even when compared to the control bread made from wheat flour. It is worth noting that the softness attribute of the $100 \%$ taro flour formulation was the only one that presented differences with the other formulations, including to that of control, as it was tougher, what can be attributed to the absence of gluten, a viscoelastic protein contained in wheat flour that gives the bread its peculiar characteristic. 
The type of bread used as a reference obtained the best average in all the parameters when compared to those made with taro flour, hence the acceptability index of $99.7 \%$ attained. The purchase intention by food evaluators is a market analysis tool, since $90.6 \%$ expressed the intention to buy bread formulated only with taro flour, which may have resulted from the awareness of the nutritional and medicinal characteristics of the tuber and the concern for improving the quality of health. The bread formulated with 30 and $50 \%$ replacement of wheat flour both obtained $94.6 \%$ of the purchase intention, and so can be considered a potential product for the bakery market.

Sharma et al. [23] state that the acceptability of taro flour bread decreases as the proportion of mixture increases, and refer that an inclusion level above $15 \%$ of taro flour does not differ significantly in attributes when compared to the control variant. In this work, the partial replacement of wheat flour was of 30 and $50 \%$ of taro flour, having achieved a positive average in terms of acceptability, which did not affect the degree of sensory acceptability of consumers. According to Njintang et al. [31], in order to guarantee the quality of bread made with partial replacement of taro flour, the level of inclusion cannot exceed 10\%, while Ammar et al. [32] concluded that the $10 \%$ substitution does not affect the organoleptic properties and is similar to wheat flour bread. Interestingly, the data in this study show an acceptability index of $86 \%$ for bread formulated only with taro flour, what is considered good, since it is above $80 \%$. The formulation made with substitution of taro flour at 30\% revealed an acceptability index of $94.4 \%$, against that of $97 \%$ of the bread with an inclusion level of 50\%, both considered excellent for presenting values above $90 \%$, as, according to Teixeira et al. [33], the product is considered accepted for its sensory properties when it obtains an acceptability index of at least $70 \%$. The acceptability obtained in this study is considered satisfactory mainly because it is a new product developed [34]. A study by Alflen et al. [35] reveals the possibility of increasing the levels of inclusion of taro flour above $30 \%$ without significant differences in its attributes. The data from this study confirm the veracity of what was expressed by the authors mentioned above because $50 \%$ of the taro flour was included without really having a significant difference between the attributes.

Norhidayah et al. [36] have produced biscuits from green banana flour with an inclusion level above 50\% in replacement of wheat flour and they considered to have obtained a good quality product. The data of this work indicate the possibility of using taro to obtain flour to make bread and other bakery products, and, therefore, reduce the costs that involve the importation of wheat in Angola.

\section{Conclusion}

Taro has revealed to be an excellent raw material for obtaining flour and making bread of good quality which is acceptable to consumers. Mixing at different levels of inclusion with wheat flour can be a viable alternative in bread making.

\section{References}

[1] Aquino, A. C. M. S., Santos, J. C., Castro, A. A., Silva, G. F. (2011). Physicochemical and microbiological characterization of yam flour during storage in different packages. Scientia Plena, 7(11): 9901.

[2] Adebowale, A. A.-R., Wahab, A. B., Sobukola, P. O., Obadina, A. O., Kajihausa, E. O., Adegunwa, O. M., Sanni, O. L., Tomlins, K. (2018). The antinutritional and vitamin composition of high-quality yam flour as affected by yam specie, pretreatment, and drying method. Food Sci Nutr., 6: 1985-1990.

[3] Zárate, N. A. H., Vieira, M. C. (2006). Nutritive composition of rhizomes of yam clone cultivated in Dourados-MS. Tropical Agricultural Research, 34(1): 61-63.

[4] Jheng, Y. J., Tsai, W.-Y., Chen, K.-H., Lin, K.-W., Chyan, C.-L., Yang, C. C., Lin, K.-C. (2012). Recombinant dioscorins of the yam storage protein expressed in Escherichia coli exhibit antioxidant and immunomodulatory activities. Protein Expression and Purification, 85(1): 77-85.

[5] Ubalua, A. O. (2016). Cocoyam (taro and tannia): staples with untapped enormous potentialsa review. Plant Knowledge Journal, (5): 27-35.

[6] Kaushal, P., Kumar, V., Sharma, H. (2015). Utilization of taro (Colocasia esculenta): a review. J Food Sci Technol., 52(1): 27-40.

[7] Arici, M., Yildirim, R. M., Ozulku, G., Yasar, B., Toker, O. S. (2016). Physicochemical and nutritional properties of taro flour as affected by drying temperature and air velocity. LWT - Food Science and Technology, (74): 434-440. Available from: $<$ https://www.sciencedirect.com/science/article/pii/.

[8] Kumar, S., Das, G., Shin, H.-S., Patra, J. K. (2017). Dioscorea spp. (A Wild Edible Tuber): A Study on Its Ethnopharmacological Potential and Traditional Use by the Local People of Similipal Biosphere Reserve, India. Frontiers in Pharmacology, $8(52)$.

[9] Trinidad, T. P., Mallillin, A. C., Loyola, A. C., Encabo, R. R., and Sagum, R. S. (2010). Nutritional and Health Benefits of Root Crops. In Bioactive Foods in Promoting Health, 717-728. 
[10] Abera, G., Solomon, W. K., and Bultosa, G. (2017). Effect of drying methods and blending ratios on dough rheological properties, physical and sensory properties of wheat-taro flour composite bread. Food Science \& Nutrition, 5(3): 653-661.

[11] Ribeiro, M., Nunes, F. M., Rodriguez-Quijano, M., Carrillo, J. M., Branlard, G., and Igrejas, G. (2018). Next-generation therapies for celiac disease: The gluten-targeted approaches. Trends in Food Science and Technology, 75, 56-71.

[12] Chapoto, A. G., Jones Haggblade, Steven Jayne, Thomas, S. (2010). Staple food prices in Zambia. Comesa Policy Seminar 'Variation in staple food price: Cause, consequence and policy options' Maputo, Mozambique, 25-26. Common market for Eastern and Southern Africa, Lusaka, Zambia.

[13] Naguma, M. B. (2020). Bread making potentials of flour from taro (Colocasia esculenta L.) as a partial substitute of wheat flour. In Partial Fulfillment of the Requirements for the Degree of Master of Science in Food Science and Technology.

[14] Oliveira, N. A. (2018). Development of gluten-free yam bread. Dissertation thesis of Nutritional course in São Lucas University Center, Porto Velho-RO, Brasil.

[15] Dias, J. S. R., Mendes, F. Z. C., Nolasco, M. V. F. M., Bogo, D. (2020). Obtaining yam flour for the preparation of cereal bar as a food and functional supplement. Brazilian Journal of Development, 6(3): 15716-15735. Available from: <http://www.brjd.com.br/index.php/BRJD/article/view/8196/7066>. Accessed: Apr. 22, 2020. doi: 10.34117/bjdv6n3-446.

[16] FAO. FAOSTAT. Countries by commodity. (2017). Disponível em: <http://www.fao.org/faostat/en/\#rankings/countries_by_ commodity>. Acesso em: 05 out.2020.

[17] Temesgen, M., Negussie, R. (2015). Nutritional Potential, Health and Food Security Benefits of Taro Colocasia Esculenta (L.): A Review. Food Science and Quality Management, 36: 23-30.

[18] Cunha, A. P., Silva, A. P., Roque, O. R. (2006). Plants and vegetable products in herbal medicine. Colouste Gulbenkian Foundation. Education and Scholarships Service. Lisboa-Portugal (2ed.): 21-54.

[19] Bernard, H. R. (1994). Research Methods in Anthropology: Qualitative and Qualitative approaches. $2^{\text {nd }}$ ed. Walnut Creek, Canada: Sage publications, 585.

[20] Almeida, E. P., Travassos, A. E. R., Moreira, R. T., Santos, E. P. (2006). Use of goat's milk to make butter cheese. In: National Conference of Agroindustry, 1. BRASIL.

[21] Teixeira, E., Meinert, E. M. Barbetta, P. A. (1987). Sensory Methods. In: Teixeira, E; Meinert, EM; Barbetta, PA. Sensory Analyses of Foods. Florianópolis: UFSC: 66-119.

[22] Basseto, R. Z., Samulak, R., Misugi, C., Barana, A., Rosso, N. (2013). Biscuit prodution with beet processing (Beta vulgaris L.) Revista Verde, 8(1): 139-145.

[23] Sharma, H. K., Njintang, N. Y., Singhal, R. S., and Kaushal, P. (2016). Tropical Roots and Tubers: Production, Processing and Technology. Department of Food Engineering and Technology, Sant Longowal Institute of Engineering and Technology, Sangrur, India.

[24] Miamoto, J. B. M. (2008). Obtaining and characterizing a cookie made with yam flour. Minings: UFLA.

[25] Sá, A. R. A., De Lima, M. B,, Silva, E. I. G., Mendes, M. L. M., Messias, C. M. B. de O. (2018). Physicochemical and nutritional characterization of flour obtained from yam (Dioscorea spp.) and taro (Colocasia esculenta) commercialized in Petrolina-PE. Health (Santa Maria), 44(3): 1-9.

[26] Sanful, R. E. (2011). Organoleptic and Nutritional Analysis of Taro and Wheat Flour Composite Bread. World Journal of Dairy Food Science, 6(2): 175-179.

[27] Mongi, R. J., Ndabikunze, B. K., Chove, B. E., Mamiro, P., Ruhembe, C. C., Ntwenya, J. G. (2011). Proximate composition, bread characteristics and sensory evaluation of cocoyam-wheat composite breads. African Journal of Food, Agriculture, Nutrition and Development, 11(7): 260-272.

[28] Ndabikunze, B. K., Talwana, H. A. L., Mongi, R. J., Issa-Zacharia, A., Serem A. K., Palapala, V., Nandi, J. O. M. (2011). Proximate and mineral composition of cocoyam (Colocasia esculenta L. and Xanthosoma sagittifolium L.) grown along the Lake Victoria Basin in Tanzania and Uganda. African Journal of Food Science, 5(4): 248-254.

[29] Zárate, N. A. H., Vieira, M. C., Tabaldi, L. A. Gassi, R. P., Kusano, A. M., Maeda, A. K. M. (2012). Agro-economic production of taro as a function of the numbers of heaps. Seminar: Agricultural Sciences, 33(4): 1673-1680.

[30] Reis, G. D. (2011). Evaluation of the bilogical activity taro [(Colocasia esculenta (L.) Schott)] in the Artemia salina Leach lethality assay, in antifungal broth microdilution test and in rabbit hypercholesterolemia [Manuscript].

[31] Njintang, N. Y., M. F. Carl, B. Facho, K. Pierre, and S. Joel. (2008). Effect of taro (Colocasia esculenta) flour addition on the functional and alveographic properties of wheat flour and dough. Journal of the science of food and Agriculture, 88: 273-279.

[32] Ammar, M. S., Hegazy, A. E., Bedeir, S. H. (2009). Using of Taro Flour as Partial Substitute of Wheat Flour in Bread Making. World Journal of Dairy \& Food Sciences, 4(2): 94-99.

[33] Brasil. Ministério da Agricultura, Pecuária e Abastecimento (MAPA). (2010). Manual of unconventional vegetable. Secretariat of Agricultural Development and Cooperatives. Brasília: Maps/ACS.

[34] Franco, V. A. (2015). Development of gluten-free bread with rice and sweet potatoes flour. Dissertation thesis, UFG, Brasil. 
[35] Alflen, T. A., Quast, E., Bertan, L. C., Bainy, E. M. (2016). Partial substitution of wheat flour with taro (Colocasia esculenta) flour on cookie quality. RECEN, 18(2): 202-212.

[36] Norhidayah, M., Noorlaila, A., Nur Fatin Izzati, A. (2014). Textural and sensorial properties of cookies prepared by partial substitution of wheat flour with unripe banana (Musa x paradisiaca var. Tanduk and Musa acuminata var. Emas) flour. International Food Research Journal, 21(6): 2133-2139. 